\title{
DE ONTWIKKELING VAN DEN POLITIEKEN TOESTAND OP DE NEDERLANDSE ANTILLEN
}

DOOR

\section{MR B. DE GAAY FORTMAN}

De politieke gebeurteurtenissen op de Nederlandse Antillen na de Maart-verkiezingen moeten allen, die het wèl menen met dit gebiedsdeel, met zorg vervullen. Het leek zo mooi. Ook zij, die in de politieke rijpheid van de kiezerscorpsen der verschillende eilanden nog moeilijk konden geloven, hebben moeten toegeven, dat althans een politieke gedisciplineerdheid bij die verkiezingen gebleken is, die getuigt van een groot vertrouwen der kiezers in hun leidslieden, waardoor de politieke aansprakelijkheid, door een massa niet te dragen, gebracht wordt daar, waar zij controleerbaar is.

De leider der Nationale partij, die met zeven statenleden (4 op Curaçao en 3 op de bovenwindse eilanden) uit de stembus gekomen was, aanvaardde een opdracht van den gouverneur om een voordracht van candidaten voor het College van algemeen bestuur in te dienen, daarbij strevende naar een zodanige samenstelling, dat het College zou mogen rekenen op een vaste meerderheid in de Staten. Deze opdracht lag te meer voor de hand, omdat inmiddels bekend geworden was, dat de Nationale partij een ,coalitie" had aangegaan met de Arubase volkspartij, waarbij ook een der afgevaardigden van Bonaire kon gerekend worden. $4+3+5+1=13$ is ons voorgerekend, en tegenover die 13 zouden 8 vogels van verschillend gevederte staan.

Heeft de gouverneur in zijn opdracht deze vaste meerderheid van 13 bedoeld? Wie zal het zeggen? Beurs- en Nieuwsberichten van 23 Mrt. 1949 gaf een verslag van een gesprek met den voorzitter der Nationale partij, waarin men tevergeefs zoekt naar het gezamenlijk program van actie van beide ,,volks"'-partijen, maar wel een samenwerking van den ,leider van ons parlementaire leven" met de andere partijen als mogelijk verondersteld wordt. Het blad zelf blijkt omtrent een en ander niet zeer hoopvol te 
zijn; het herinnert aan den vergeefsen Canossagang van den genoemden ,"leider" naar het bisschoppelijk Paleis, spreekt van „,de wankele pilaren van Van Poelje” als grondslag der „,coalitie”, en vraagt welke concessies de Arubase leider daaruit weer zal wringen.

Van werkelijk overleg met andere partijleiders door den „Kabinetsformateur" blijkt alleen, dat de tachtigjarige frater Radulphus, de R. K. onderwijsman, voor "Onderwijs" zou zijn aangezocht maar bedankt zou hebben. Ten slotte werden aan den gouverneur 6 leden voorgedragen, van welke 3 ,nationalisten” zijn, 1 Arubaan, die ,zonder portefeuille" zou meedoen, en 2 wilden. Nauwelijks waren de namen bekend, of in de kringen der oppositie stak een storm van verontwaardiging op, nog vóór bekend was, of de gouverneur de voorgedragenen zou benoemen. In het negatieve bleek de oppositie één.

Art. 68 der Staatsregeling eist overleg met de Staten over de benoeming van het College van advies, en dit overleg werd aan den ,,formateur" opgedragen. Hoe dit overleg heeft plaats gehad is begrijpelijkerwijs niet officieel bekend geworden, maar het Algemeen Handelsblad van 4 Mei ll. wist mee te delen, dat met 11 tegen 9 stemmen de Staten hun goedkeuring aan het zestal gegeven hebben, en dat de bezwaren waren de ongeschiktheid van den Arubaan voor een bestuursfunctie en de jeugd van den voor ,Sociale en economische zaken" voorgedragen doctorandus, die juist den 29 jarigen leeftijd bereikt heeft. Aan deze stemming moeten dan de twee voorgedragen Statenleden deelgenomen hebben. In de openbare vergadering van $3 \mathrm{Mei}$, waarvan alleen nog krantenverslagen ter beschikking staan, werden echter heel wat krasser dingen gezegd. In het College praevaleerde het eigenbelang volgens de ene spreker; er zijn ,politieke wouwelaars” onder, en ik kan hen niet allen ,eerlijk en bekwaam" noemen, zei een ander; ,,politieke avonturiers” qualificeerde een derde.

Dit zijn allemaal woorden, die ondanks - neen, juist om - de parlementaire onschendbaarheid niet door de beugel kunnen. Een parlementariër moet zich ook parlementair kunnen uitdrukken, en dat vooral, als een politieke hartstochtelijkheid dreigt zich van hem meester te maken. In deze vergadering droeg alles er toe bij om de stemming geladen te maken. Een voorzitter, die in beleid te kort schoot, een joelend publiek op de tribune in de raadzaal en daarbuiten, allerlei politieke verrassingen. Voor deze laatste zorgde o.a. het Arubase lid, dat zijn neiging tot de Democratische partij al eerder niet onder stoelen 
of banken stak, en nu zich openlijk tegen de leiding der Arubaanse volkspartij verzette.

Dat de voorzitter de publieke tribune liet ontruimen, lijkt, naar de krantenverslagen te oordelen, juist. Het Arubase adagium ,,vox populi vox Dei” is een onwaarheid ,en mag zeker in een democratische volksvertegenwoordiging niet gelden. Maar die voorzitter schoot te kort, toen hij niet aanstonds, en zelfs niet, toen hij op den eis der staatsregeling gewezen werd, voorstelde de stemming voor de plaats van voorzitter der Staten ,,bij gesloten en ongetekende briefjes" te doen plaatsvinden. Ook het verloop van deze zaak behoort tot de onverkwikkelijke dingen der jongste politiek op de Nederlandse Antillen. De voordracht was voorbereid in de vergadering van de commissiën, die enige jaren geleden de ,afdelingen” der Staten moesten vervangen, zogenaamd om aan de geheime voorbereiding van de openbare behandeling der zaken een einde te maken, maar dit doel allerminst bereikt hebben. Als no. 1 was door die commissie voorgedragen een afwezig lid der Nationale partij, en toen het op een latere vergadering toch tot een geheime stemming moest komen, kwam het afgescheiden lid der Arubaanse volkspartij uit de bus. Het geval doet denken aan de Overijsselse kwescie van 40 jaar geleden, en wijst evenals dat op zekere politieke ontaarding, ook al doordat alle tien daarvoor in aanmerking komende coalitieieden in een daarna gehouden partijvergadering zouden hebben verklaard te hebben gestemd op den candidaat, die slechts 8 stemmen kreeg.

De gouverneur benoemde de voorgedragenen in de Commissie van algemeen bestuur en ook den oppositiecandidaat op de voorzittersstoel.

Er zou nog meer politieke verwarring komen. Een tweede lid der Arubaanse volkspartij heeft zich van zijn ,leider" losgemaakt. In een pamflet, door hen beiden onderschreven, beschuldigen beide afgescheiden leden den voorzitter der partij ervan het Arubase volk te hebben verraden door de Interimregeling te stellen boven het plan-Van Poelje. Dit worden onzuivere politieke verhoudingen. Men moet de partij laten uitspraak doen, en, als zij dat gedaan heeft, zullen de door haar verloochende leden zich ernstig moeten afvragen wat hun te doen staat, en dat kan m.i. niet twijfelachtig zijn.

Zo wankelt de coalitie. De Arubaanse partij ziet haar zetels van 5 tot 3 slinken, en alles bij elkaar kan het regeringsblok nog maar op 11 van de 21 zetels rekenen. Reeds heeft de coalitie, 


\section{MR B. DE GAAY FORTMAN, DE ONTWIKKELING VAN DEN}

welker sterkte tijdelijk nog verminderd was, omdat een lid in het buitenland vertoefde en twee van haar leden nog niet beëdigd waren, tweemaal door wegblijven een vergadering der Staten onmogelijk gemaakt. Een klein, in de zuivere politiek niet toegelaten middel, naar mij voorkomt. Anderzijds mag men van een loyale oppositie verwachten, dat zij geen misbruik maakt van een toevallige meerderheid, die de tegenpartij ook niet door trouwe opkomst kan verhinderen.

Toen er eindelijk 9 Juni vergadering kon worden gehouden, bleken er 6 coalitie- en 9 oppositiemannen aanwezig. Met dezelfde stemmenverhouding werd een motie van wantrouwen in de Commissie van algemeen bestuur aangenomen. Daarin wordt gesproken over het zwaarder hebben laten wegen van partijpolitieke dan landsbelangen bij de samenstelling, en van het doen gelden van politieke gezindheid boven bekwaamheid. Ook wordt gezegd, dat de mogelijkheid om een sterk en bekwaam College van algemeen bestuur, te vormen aanwezig is, mits de al te eenzijdige partijdigheid wijkt voor het algemeen belang.

$\mathrm{Na}$ aanneming der motie stapte de oppositie op, de voortzetting der vergadering, waarin o.m. de toelating van twee nieuwe leden van de N.V.P. aan de orde had moeten komen, onmogelijk makende. Hiervan kan niet anders gezegd worden, dan van het niet-komen der coalitie op de twee vorige vergaderingen.

De leden der Commissie van algemeen bestuur hebben natuurlijk den gouverneur hun ontslag aangeboden.

Wat moet men van deze dingen zeggen? Het beleid van den voorzitter der Nationale volkspartij vertoont zekere tekortkomingen. Zijn houding ten opzichte van de R. K. volkspartij, die hem in de staten bracht, kan niet bewonderd worden. Zijn poging om zijn Nationale partij als de alleen-nodige uit te roepen wijst niet op gezonde politieke opvattingen. De coalitie met de Arubaanse partij heeft weinig dieperen zin dan die van het cijfer. De samenstelling van de voordracht voor het College van algemeen bestuur, waarbij de Statenfractie der Nationale partij van haar sterkste krachten werd beroofd, wettigt ook uit anderen hoofde de vraag welk landsbelang daarbij voorgezeten heeft. Dat daarbij een plaats is ingeruimd aan een veelbesproken figuur als het Arubaanse lid, zegt, politiek gesproken, genoeg.

Bij dit alles komt de verdenking, gerezen tegen een der leden van de Commissie van algemeen bestuur, en de Amigoe weet mee te delen, dat de toelating van een der nieuwe leden wel op 
moeilijkheden zal stuiten in verband met bepaalde gepleegde onregelmatigheden. De politieke barometer der Nederlandse Antillen is gedaald. Heeft ook nog niet de procureur-generaal bij het Hof van justitie meegedeeld, dat vele woorden, in deze verkiezingsstrijd gesproken, over de grens der wettelijke toelaatbaarheid gingen?

Maar nu de oplossing van het politiek conflict. Hierbij komen zoveel vragen naar voren, dat zij niet voor de hand schijnt te liggen. De oppositie van nu is een schijneenheid. De tegenstelling Aruba-Curaçao is groot en daarom ook was de coalitie Curaçao-Aruba zo vreemd. De Democraten kent men uit de vorige Staten en de Ronde-tafel-conferentie. In politiek opzicht staan zij en de nationalisten eigenlijk elkaar het naast. Zal de Nationale Volkspartij, zal haar leider, na dit echec zo groot zijn om in of buiten een nieuwe Commissie van algemeen bestuur aan het landsbelang mee te werken?

Een partijpolitieke oplossing schijnt er niet te zijn. Dan maar geen partijpolitiek en slechts landspolitiek! Er zullen in de Nederlandse Antillen zeker mensen zijn van voldoende erkende bekwaamheid om het scheepje van staat te besturen. $\mathrm{Zij}$ mogen ook bereid gevonden worden!

19 Juli 1949.

Tot zo ver schreef ik twee weken geleden. Na dien zijn nadere berichten gekomen omtrent de onregelmatigheden, bij de verkiezingen gepleegd. Het blijkt, dat de afgevaardigde van een der bovenwindse eilanden vóór de indiening van een candidatenlijst daarop na de ondertekening door de kiezers een candidaat bijgeplaatst heeft. Het openbaar ministerie heeft daarin een strafbaar feit gezien en tegen den verdachte, die reeds ontslag nam als lid der commissie van algemeen bestuur, een voorlopig onderzoek bevolen. Dit zijn ernstige dingen, en de Curaçaose kranten staan er vol van. Het gaat daarmee al net als hier. De redactie begint met te verklaren, dat zij zich niet over de zaak zal uitlaten, daar zij ,onder den rechter" is, maar intussen...! Waarom zou ,,men" zijn mening niet mogen zeggen? De rechter zal er zich niet door laten beïnvloeden In dien zin is rechtspraak geen vox Dei. Maar men moet zijn mening zeggen met verstand en het bijvoorbeeld niet doen voorkomen, alsof de fout is, dat de dader achteraf de kiezers-ondertekenaars van de lijst niet op de hoogte gebracht heeft, want toen was het kwaad gedaan. Het is een ernstig ding. Vooral als men de zaak uit politiek oogpunt

West-Indische Gids XXX 


\section{MR B. DE GAAY FORTMAN, DE ONTWIKKELING VAN DEN}

beziet. Als men kwade trouw uitschakelt, moet men wel belanden bij politieke onrijpheid van een leider. En daarom doet het er betrekkelijk weinig toe wat de uitspraak is ${ }^{1}$ ) Waarschijnlijk heeft ook de persoon zelf dit ingezien en daarom ontslag gevraagd uit het C.A.B.

Er zijn meer dingen, waarover men op de Curaçaose eilanden ernstig klaagt. De begroting voor 1949 is nog steeds niet behandeld, en die voor 1950 is reeds enige weken geleden verschenen. Over de voorgestelde interimregeling is nog steeds door de staten geen advies uitgebracht.

Grote werken, die reeds lang op het program staan, als de bouw van een postkantoor en van een brug over de St. Annabaai, brengen het niet tot uitvoering. Op Curaçao heerst watergebrek, en men fluistert, dat het gouvernement over te weinig kasgelden beschikt voor nodige betalingen.

Het zijn vooral bladen als Democraat en Curaçao, die op verschillende wondeplekken in de samenleving den nadruk leggen. Het laatstgenoemde blad haalt uit het eerste een en ander aan uit een artikel „Gezag te Grabbel”. Dit staat nog niet tot mijn beschikking, maar wel de Democraat van half Mei ll., die een „Open brief aan de Staten-generaal" bevat. Daarin wordt o.a. gewezen op de verandering der staatsregeling ongeveer een jaar geleden, die de zelfstandigheid van Aruba heeft menen op te lossen met een verdeling der Statenzetels op een wijze, die met die zelfstandigheid niets te maken had en spot met de democratie.

Dàt is het wat velen hoog zit: Curaçao, de meerderheid der kiezers, dreigt door een minderheid overheerst te worden. De Democraat wijst op het zonderlinge, dat de voorgestelde interimregeling wel de mogelijkheid van een andere zetelverdeling opent, maar die overlaat aan Staten, die dan hun eigen graf moeten graven. Een aantal Curaçaoenaars heeft aan de Koningin 23 Mei 1l. een adres gestuurd, waarin aangedrongen wordt op herziening der zetelverdeling. Het spreekt van een gevoel van onvoldaanheid bij hen, die de gang van zaken nauwlettend volgen, van ontevredenheid, die bij steeds grotere groepen waar te nemen is, en vraagt subsidiair algehele administratieve en financiële scheiding, zover mogelijk, op het terrein van wetgeving, belastingheffing en wat ambtenaren betreft, voor Curaçao.

1) De verdachte is vrijgesproken van het hem te laste gelegde strafbare feit. 
POLITIEKEN TOESTAND OP DE NEDERLANDSE ANTILLEN 243

Curaçao legt de vinger op een wonde-, en voor Nederland uiterst pijnlijke plek, als het erop wijst, dat het Nederlandse bestuur - duidelijk is hier bedoeld: de regering in Nederland ,de huidige deplorabele toestand in de hand heeft gewerkt .... door gebrek aan inzicht en leiding"'.

De juistheid de̊zer beschuldiging zal niet gemakkelijk weerlegd kunnen worden.

3 Juli '49 